\title{
ЕПИТЕТИ ВЕЗАНИ ЗА ГРАД ТЕМИШВАР У СРПСКОЈ ПОСЛЕРАТНОЈ ШТАМПИ
}

\begin{abstract}
Град Темишвар са околином заузимао је значајно место у политици разграничења Краљевине Срба, Хрвата и Словенаца на мировној конференцији у Паризу. Територијалне претензије југословенске Владе и њене делегације на Темишвар правдане су војним победама и присуством војске у спорним подручјима, историјским правом, као и жељама са̂мог становништва које је тамо живело. Међутим, значајно је приказати какву је улогу у разграничењу имало и јавно мњење у Краљевини СХС. Да би се код читаоца створила слика о важности Темишвара за српску страну, у штампи је посебна пажња посвећена епитетима и синтагмама који су описивали овај град. Аутори чланака представљали су га позитивно и поетично, на пример као: „банатски бисер” или „наша дика”... У раду ћемо изложити бројне епитете које су уредништва српских листова и аутори новинских чланака користили пишући о Темишвару непосредно након Првог светског рата. Дајемо и један шири историјски контекст који прати и показује колико је српској страни било важно да ова банатска престоница припадне Краљевини СXС.
\end{abstract}

Кључне речи: Темишвар, Срби у Темишвару, српска штампа, Краљевина СХС, разграничење.

Након завршетка Првог светског рата, Велике силе су прекрајале мапу Европе. У извесној мери, делегације осталих земаља победница могле су да утичу на исход разграничења. Дипломатска борба одвијала се на Конференцији мира за зеленим столом у Паризу, али и на терену путем разних политичких мисија и јавног мњења. [види више: Mitrović: 1975] Југословенска делегација требало је да убеди представнике Великих сила у основаност југословенског права на Банат и на Темишвар, а верујући да би као решење банатског питања могао да се узме принцип народне консултације југословенска страна требала је да убеди и остале групе народа који су живели у Темишвару да на евентуалном плебисциту гласају за југословенску опцију. У таквој политици разграничења дневна штампа је у извесној мери представљала значајан фактор. Да би се у јавном мњењу створила слика колико је Темишвар значајан по српску страну у штампи је нагласак, осим на историјске чињенице и на историјско право, стављан и на епитете везане за Те-

1 majovanakasas@yahoo.com 
мишвар и они су очекивано позитивног карактера. Када се писало о томе да је Темишвар место око којег се споре румунска и југословенска страна онда су те синтагме негативног карактера и умањују његову вредност па се тако писало да је спор избио због „малог комадића земље”. У осталим примерима углавном се ради о епитетима и кованицама које су поетичног карактера и код читалаца је требало да изазову одређену реакцију. У раду износимо синтагме и епитете које смо проналазили током истраживања и које смо у раду поделили на неколико група. На оне који се односе на стратегијски значај Темишвара, на оне које се односе на историјско право и на емотивну вредност југословенске стране, на оне које се односе на сукоб са Румунима и на оне које представљају историјску прошлост Темишвара. У питању је био, у највећој мери, истраживачки рад на војвођанској штампи на српском језику која се чува у периодици Матице српске у Новом Саду.

Након револуције 1848/49. године град Темишвар изабран је да буде престоница Српске Војводине до 1861. године када је она била укинута. [види више: Микавица: 2011] Позивајући се на историјску прошлост и на историјско право, лист Банаћанин је након разграничења писао да је Темишвар некада био „центар” и „престоница нашег Баната” [Cpби y Teмишвару!, Банаћанин, бр. 71, Вршац, 10. септембар 1922, стр. 2.], док је новосадски лист Застава истицао да „ма колико да је Српска Војводина од 1848. била кратког века и трошна, ипак јој је Темишвар био центар, ипак је Банат ма и полузванично био српски, а никад румунски" [Застава, бр. 145, Нови Сад, 1. јул 1921, стр. 2.] „Темишвар је од увек био престоница српске Војводине, и да би тај центар уништили званични кругови аустријски и мађарски гледали су да га униште тиме што су га насељавали Јеврејима и Немцима. Но поред свега тога, Темишвар ипак није изгубио своју стару слику. Он и даље остаде центар Баната, па према томе и центар банатских Срба", писало је и уредништво листа Слога након уласка српске војске у Темишвар. [Зашто је Банат наш?, Слога, бр. 53, Темишвар, 14. фебруар 1919, стр. 1.] У штампи, Темишвар је називан „престоницом Српске Војводине” односно „престоницом Српске Војводовине”, а како би се још више указало на повезаност Темишвара са југословенском државом неретко је додавана реч „наша”, односно „наша војвођанска престоница [Вршачко сунце и сенке, Нова зора, бр. 45, 22. јун 1919, стр. 1.], или „изгубили смо дакле центар наше Војводине - Темишвар” и „ми смо изгубили престолницу наше Војводине где нас је звала прошлост и традиција" [Глас из душе!, Банатски гласник, бр. 156, Велики Бечкерек, 1. август 1919, стр 1.] Као и „средиште наше старе Војводине” и „престоница нашег Баната где нас све на нашу стару славу потсећа" како је дефинисао национални делатник Новак Грујић из Варјаша [Новак Грујић, Слога, бр. 261, Велики Бечкерек, 13. новембар 1919, стр. 1.]

Након пробоја Солунског фронта и завршетка Првог светског рата, у 
складу са својим ратним циљевима који су били да се ослободи сва неослобођена браћа, српска војска је напредовала према Темишвару. [Bjelajac: 1988] „Ето иду, долазе! У том затрешта победна труба уз топот брзе коњице и, пред некадашњим царским магистратом, на очиглед српског владичанског двора, српске цркве и српских гробова, витез за витезом у оклопу и шлемовима грунуо је пред капију града Темишвара, да 18. новембра 1918. изврши повратак у престоницу старе Војводине. И пред њиховим блаженим стопама отвориле су се капије и наскоро и срца града Темишвара", писао је Милан Л. Поповић за београдски лист Време. [Милан Л. Поповић, Време, бр. 1407, Београд, 18. новембар 1925, стр. 3.] Новосадски Српски лист писао је да је немачки лист Temesvarer Zeitung поздравио улаз српске војске у „главно место некадашње Српске Војводине” овим речима: „Јуче пре подне је српска војска посела Тамишвар... Ми смо рат изгубили и - сносимо своју судбу покорно.” [Српски лист, бр. 15. Нови Сад, 10. новембар 1918, стр. 3.]

Када је српска војска ушла у Темишвар средином новембра 1918. године на свечаном дочеку, приређеном њој у част. [Касаш, 2019: 69-87] Илија Белеслијин, члан темишварског Народног већа обратио се том приликом команданту Николи Цоловићу: „Да живи Велика Србија, да живи краљ Петар! Поздрављам вас љубављу у средишту старе српске Војводине" [Српски лист, бр. 15. Нови Сад, 10. новембар 1918, стр. 3.], а када је крајем марта 1919. године Темишвар добио новог команданта Коњичке дивизије, пуковника Бранислава Лонткијевића, испред темишварских Срба команданта је поздравио Христифор Свирчевић, члан у то време расформираног српског темишварског Народног већа и пожелео му пријатно време у Темишвару. Рекао му је да се налази у „срцу Војводине” и пожелео му да град никад не остави. [Слога, бр. 92, Темишвар, 30. март 1919, стр. 2.]

Лист Слога неретко је представљао политичке прилике кроз разне шаљиве слике из свакодневног живота. Тако је у једном броју који је изашао за време трајања српског империјума, односно док је српска војска била стационирана у Темишвару, донет разговор Глише и Трише. „Глиша: Што си такав, бре Тришо! Триша: Какав? Глиша: Глуп си као ноћ? Триша: Е, опрости, они што проповедају да ће Срби одавде отићи, глупљи су од мене сто пута. Ко сматра да Темишвар, ова војвођанска престоница није српска, тај је глуп колико и хиљаду и једна ноћ. Разумеш ли?” [Слога, бр. 104, Темишвар, 16. април 1919, стр. 2.]

Темишвар је означен као „војвођанска престоница” и у чланку под насловом „Чујте нас!” кад је уредништво истог листа тражило да се „да се чује глас и из Темишвара и да се обрати пажња на то шта Темишвар значи за Југославију, да се Београђани више интересују о овом граду, о овој војвођанској престоници, а не да га олако жртвују ради добрих односа". [Yујте нас!, Слога, бр. 83, Темишвар, 21. март 1919, стр. 1.] 
На збору против румунских претензија Шандор Поповић, члан у то време расформираног српског Народног одбора изјавио је: „Ми смо готови да бранимо наше од оних, које смо примили као просјаке у нашу цркву, а који су се после осилили тако, да се чак и за престоницу ову машају. Ми још сада велимо: одступите, идите тамо у брда код стоке и дубити шавоље, а нас оставите на миру у нашему дому. Одступите док је време и док не буде доцкан! У нама Хајдук Вељкове крви има, па велимо: Главу дајемо, ал' Темишвар не дајемо!" [Слога, бр. 147, Темишвар, 11. јун 1919, стр. 1.]

„Не могу да разумем са каквим правом захтевају Румуни нарочито Тамишвар, кад је то баш стара престоница српске Војводине и седиште једног српског епископа?", питало се уредништво листа Застава. [Застава, бр. 35, Нови Сад, 26. фебруар 1919. стр. 1.]

Међутим, у складу са одлукама Конференције мира у Паризу која је Темишвар доделила румунској држави, српска војска је од своје Владе добила наређење да се повуче из града и околине. Заједно са војском, Темишвар је напустило и уредништво листа Слога који је до тада излазио у овом граду. [види више: Касаш, 2020: 339-351] На насловној страни последњег броја који је изашао у Темишвару писало је: „Мили наш Темишвару, банатска мајко наша, престоницо наша, БУДИ НАМ ЗДРАВО!" [Слога, бр. 176, Темишвар, 19. јул 1919, стр. 1.]

Уредништво листа Слога се из Темишвара преселило у Велики Бечкерек, а уредник листа Милош Станојевић је одатле писао: „Ми смо давно чекали слободу, чекамо је још бољу и потпунију, можемо је још дуго и дуго чекати. Наш јаук и напон за потпуном слободом и уједињењем допр'о је преко Крфа чак до Бизерте. Па и сада ми не заборављамо банатску престоницу.” [М. Ст. Слога, бр. 257. Велики Бечкерек, 7. новембар 1919. стр. 1.]

Како је Темишвар и након потписивања коначних мировних уговора остао у Краљевини Румунији остало је само да се обележава дан када је српска војска ушла у Темишвар. Милан Л. Поповић је на седмогодишњицу од уласка српске војске у Темишвар за београдски лист Време писао да је у Војводини ,један град, највећи, престони град њезин, стари Темишвар поцрнео од жалости”. „У пустињи минулих снова, без плача и без суза, заогрнут сенком своје страшне судбине ћути данас Темишвар, престоница некадашње Војводине Српске са затвореним уснама, са исељеним народом, са напуштеном црквом и угушеним осећајима бескрајне туге сличне леденом обвоју на рани која зјапи... Ни спомен плоча урезана на зиду не сведочи више да је у некадашњој престоници Српске Војводине на данашњи дан јавила се Слобода, чуо се плотун и једно громко ура националне обнове наше. Све је нестало од сјаја тог. Темишвар је данас испуњен горким искуством наше јадне судбине", писао је Поповић. [Милан Л. Поповић, Bpeме, бр. 1407, Београд, 18. новембар 1925, стр. 3.

Крајем 1918. и почетком 1919. године инсистирало се на принципу са- 
моопредељења, односно на жељама становништва града Темишвара да живе у првој југословенској држави, док су економски интереси који су везивали овај град са државом Срба, Хрвата и Словенаца стављани у други план. Иако се на Конференцији мира тежило да се избегне истицање економске вредности Темишвара за нову југословенску државу, ипак смо у штампи проналазили разне примере. Темишвар је тако називан „бисерним”. [Антоније Штрбић, Вршачко сунце и сенке, Нова зора, бр. 45, 22. јун 1919, стр. 1.] Синтагму „овај банатски бисер” искористио је и Шандор Поповић у свом говору на великом народном збору одржаном 8. јуна 1919. године када је изјавио да ће престолонаследник Александар Карађорђевић као врховни командант српске војске знати да чува „Темишвар - овај банатски бисер”. [Слога, бр. 147, Темишвар, 11. јун 1919, стр. 1.]

Иван Прекајски је као председник српског темишварског Народног већа регенту Александру Карађорђевићу честитао преузимање власти у новој уједињеној Краљевини Срба, Хрвата и Словенаца из „средишта плодног Баната" 10. децембра 1918. године [Слога, бр. 4, Темишвар, 14. [1.] децембар 1918, стр. 1.], а Тима Димитријевић, национални делатник, писао је да се у југословенском јавном мњењу говорило да је Темишвар „плућа за Банат у сваком погледу" и да се претпостављало, па чак и тврдило, да „овај град Југословенима може да буде на копну оно што је Енглезима Гибралтар на мору" [Тима Димитријевић, Застава, бр. 176, Нови Сад, 22. август 1919, стр. 2.] На значај Темишвара за становништво југословенског дела Баната указало је и само уредништво листа Застава када је писало да „одсећи Тамишвар од равног Баната, значило би пресећи му артерије и одузети ваздух одузети његовом становништву”. [Застава, бр. 35, Нови Сад, 26. фебруар 1919, стр. 1-2.]

Престонички лист Enoxa донео је чланак у којем је писао о одржавању великог народног збора темишварских Срба 8. јуна 1919. године и у којем је поред општих вести кад је збор одржан и колико људи је на збору било присутно истакао да би задовољавање румунских затева ишло на штету не само српског народа него и целокупног становништва града Темишвара и да Темишвар као „центар банатске индустрије” није смео бити одсечен од банатске равнице јер би се тако сасвим економски уништио. [Протест Баната. Против очепљења Тамишвара од наме државе, Епоха, бр. 144, Београд, 11. јун 1919, стр. 1.]

За разлику од онога на чему је инсистирала штампа, у меморандумима на Конференцији мира инсистирано је на стратегијској вредности Темишвара. Односно, да је значајно да престоница будуће државе буде што више удаљена од границе. У меморандуму темишварске Епархије када је писано о стратегијског важности, Темишвар је означен као „стражна врата за Београд”. [Архив Југославије, Делегација, Ф. 3, бр. 3264, 19. августа 1919. године, Париз] На исто је упућивао и лист Застава. „Нимало није узето 
у обзир наше историјско право на Темишвар, некадашњи центар српске Војводине. И стратегијски су нам осакатили наш положај у тим крајевима, јер смо, једно, на самој равници, а друго, стешњени смо између две реке. О нашим индустријским интересима се никако није водило рачуна. Тамишвар који својом производњом нагиње југу, нашем Краљевству, припашће Румунији, ма да Румуни немају на Тамишвар права ни с историјског ни са народносног гледишта", писао је новосадски лист. [Застава, бр. 159, Нови Сад, 31. јул 1919. стр. 3.] Да је Темишвар означен као „кључ” Баната, стоји и у ранијим изворима. „Темишвар јесте кључ од цјелога Баната, кога господа Темишварци малим Бечем именују”, писао је Јоаким Вујић. [Попов, 2015: 92]

Када се говорило о сукобу са Румунима епитети и синтагме су очекивано биле негативног карактера. Ми смо пронашли: „la bête noire” [„црна звер”] и ,јабука раздора”. „Timişoara, le centre de culture du Banat a été depuis l'armistice, 'la bête noire' des rivales victorieuses, la Serbie et la Roumanie", писао је париски лист Philatelia. [Les émissions occasionnelles de Temesvar, Philatelia, №67, Paris, juin 1933, 20.] Београдски лист Време је десет година након догађаја око разграничења писао да је пад Јонела Братијануа, председника румунске Владе и председника румунске делегације у Паризу, допринео да се политичка ситуација измени, а је нова румунска Влада пристала на поделу Баната, те да је питање Темишвара тада престало да буде ,јабука раздора”. [Време, бр. 2336, Београд, 26. јун 1928, стр. 3.]

За нас су најважнији и најинтересантнији били епитети који су се односили на емотивну вредност коју је Темишвар имао за југословенску страну. У честитки коју је лист Слога објавио у једном од својих првих бројева писало је да се српско Народно веће из Темишвара надало да ће се „спасоносна власт Нове Краљевине што скорије протегнути и на мезимче њезино” притом ту мислећи на Темишвар и на Банат, и на Бачку и на Барању. [Слога, бр. 4, Темишвар, 14. [1.] децембар 1918, стр. 1.]

„Ово је наша прадедовска земља, ово је наша глава. Недајмо да је секу! Овде је живио и испустио своју душу у српској средини отац нашега краља!", поручио је једини лист на српском језику који је тада излазио у Темишвару у позиву за долазак на већ поменути велики народни збор одржан 8. јуна 1919. године у банатској престоници. [Слога, бр. 145, Темишвар, 7. јун 1919, стр. 2.] „Сакупљени у име банатског Српства да подигнемо свој глас против евентуалног губитка Темишвара, молимо и Ваше Краљевско Височанство да узме у своју моћну заштиту Темишвар као драгоцени резултат херојских подвига наше храбре војске...", стајало је у телеграму коју је престолонаследнику упутило председништво збора. [Српски гласник, бр. 43, Велика Кикинда, 15. јун 1919, стр. 3.] На истом збору, Илија Белеслијин је изјавио да ће Срби у Темишвару радије изгинути него прихватити да им се дира „њихова светиња Темишвар” када би га отргнули од мајке 
Србије и да ако би се ипак догодило да се Темишвар додели Румунима да ће Србин показати својим мачем како се српски образ и домовина чува. [Hова зора, бр. 48, Вршац, 3. јул 1919, стр. 1.]

Међутим, од када је Темишвар евакуисан од стране српске војске овај град називан је „мртвом тачком Српства”, односно наглашавано је „од када смо ову нашу дику евакуисали" [Срби у Темишвару!, Банаћанин, бр. 71, Вршац, 10. септембар 1922, стр. 2.], или пак да је српска страна незодовољна постигнутим и да се и даље тражи „оно старо српско гњездо” [Новак Грујић, Слога, бр. 261, Велики Бечкерек, 13. новембар 1919, стр. 1.]

Када је након доношења устава 1921. године и потписивања мировних уговора Темишвар за стално остао у Румунији, означаван је као „изгубљена југословенска земља". Обележавајући двадесетогодишњицу смрти Михаила Полита Десанчића 1940. године у Културно-привредном прегледу Дунавске бановине Владимир Бабић је написао да је Полит привремено сахрањен на темишварском гробљу „где још и данас лежи под забаченом хумком изгубљене југословенске земље”. [Владимир Ђ. Бабић, Поводом двадесетогодищњице смрти Михајла Полит-Десанчића, Културно-привредни преглед Дунавске бановине, свеска за април, Нови Сад, 1940, 156.]

„Коло Младих Срба”, које је основано у Темишвару у време провизоријума између српске и румунске власти и које је, захваљујући предавањима и драмским програмима које су његови чланови организовали, постало важан културни и политички чинилац темишварских Срба, заједно се са српском војском повукло из града. Свој рад наставило је у Великом Бечкереку, а путем штампе потручило је да „Темишвар, срце и главу Баната нико из успомене избрисати неће и да ће се за њега до последњег жртвовати". [Слога, бр. 203, Велики Бечкерек 2. септембар 1919, стр. 2.]

Рад завршавамо речима Милана Л. Поповића, који је желећи да обележи седмогодишњицу уласка српске војске у Темишвар у већ поменутом чланку написао: „У Темишвару остале су само наше цркве, наш владичански двор, црквене зграде и градске зидине као катакомбе порушене престонице нашег некадашњег сјаја, да у дубини прошлости и даље чувају сан да не измакне и да се не изгуби тамо у даљини која се јавља сваког јутра и ишчезне сваке вечери.” „Хоће ли се бар једна ласта из отаџбине винути данас тамо, тамо, у ту нашу даљину?”, писао је Поповић. [Милан Л. Поповић, Време, бр. 1407, Београд, 18. новембар 1925, стр. 3.]

\section{Извори и литература:}

Необјављени извори:

Архив Југославије, Фонд 3, Делегација на Конференцији мира 
Књиге:

Bjelajac, 1988: M. Bjelajac, Vojska Kraljevine Srba,Hrvata i Slovenaca 19181921, Beograd: Narodna knjiga.

Микавица, 2011: Д. Микавица, Српско питање на Угарском сабору 19601918, Нови Сад: Филозофски факултет, Одсек за историју.

Mitrović, 1975: A. Mitrović, Razraničenje Jugoslavije sa Mađarskom i Rumunijom 1919-1920, Novi Sad: Institut za izučavanje istorije Vojvodine.

Чланци:

Касаш, 2019: Ј. Касаш, „Живели,соколови моји!”-Улазак војске Краљевине Србије у Темишвар, Нови Сад: Темишварски зборник, бр. 11, 69-87.

Касаш, 2020: J. Касаш, Сеоба темишварских Срба након одласка српске војске у складу са одлукама мировне конференције у Паризу 1919. године, Нови Сад: Сеобе од Антике до данас, 339-351.

Попов, 2015: Д. Попов, О Темишвару и темишварским Србима из времена Бранковог школовања (1841-1843), Темишвар: Радичевићи у Teмимвару, 89-102.

Штампа:

Банаћанин, Панчево (1922)

Банатски гласник, Велики Бечкерек (1919)

Време, Београд $(1925,1928)$

Застава, Нови Сад (1919)

Јединство, Нови Сад (1919)

Културно-привредни преглед Дунавске бановине (1940)

Нова зора, Вршац (1919)

Philatelia, Paris (1933)

Слога, Темишвар (1919)

Српски гласник, Велика Кикинда (1919) 


\title{
LES ÉPITHÈTES ASSOCIÉES À LA VILLE DE TIMIŞOARA DANS LA PRESSE SERBE D'APRÈS-GUERRE
}

\begin{abstract}
Résumé
La ville de Timişoara a occupé une place importante dans la politique de la démarcation du Royaume des Serbes, Croates et Slovènes lors de la conférence de paix à Paris. Les revendications territoriales du Gouvernement yougoslave et de sa délégation à Paris envers Timișoara et ses environs sont justifiées par les victoires et la force militaires, la loi historique ainsi que les attitudes et les souhaits de la population de la zone contestée. Cependant, il est également essentiel de savoir quel rôle l'opinion publique du Royaume de la SCS a joué à cet égard. Afin de créer une image de l'importance de cette ville pour les Serbes, la presse accorde une attention particulière aux épithètes et aux syntagmes qui décrivent Timişoara. Cette agglomération y a été décrite positivement et poétiquement. Dans la presse elle est présentée par comme exemple: «la perle de Banat» ou «la clé de Banat»... C'est pourquoi dans notre article nous présenterons et expliquerons de nombreuses épithètes que les auteurs ont utilisées en écrivant sur Timișoara dans les années d'après-guerre. Nous donnerons un contexte historique plus large qui montre l'importance de cette ville d'appartenir au Royaume de SCS.
\end{abstract}

Mots-clés: Timisoara, Serbes de Timisoara, la presse serbe, Royaume SCS, démarcation. 